\title{
Kunstnik ja nimi
}

Virve Sarapik

\section{Kunst ja verbaalne invasioon}

Mingil määral on igasugune kunstiakt amoraalne. Kunstile on olemuslik invasioon ja seda võib pidada üheks postmodernse või ka kogu sõjajärgse kunsti peamiseks tunnusjooneks. Hõlvates üha uusi valdkondi on kunst amoraalne nii materiaalses kui ka vaimses mõttes - see on kunst kui vägivald, kunst kui raiskamine ja raiskamine kunsti nimel.

Kunsti kalduvus invasiooniks avaldub kõigepealt selle ruumilistes dimensioonides. Kui varem oli teoseks üksikobjekt, siis 20. sajandil on selle piirid järk-järgult laienenud. Immanentseks teoseks muutub näitus kui tervik, projekt, mis võib hõlmata terveid piirkondi. Nähtus on huvipakkuv sellelgi taustal, et modernismi algust iseloomustas vastupidine - teoste märgatavalt tagasihoidlikumad mõõtmed 19. sajandi ametlike vooludega võrreldes. Kaude ongi ruumiline invasioon kõrvutatav hilisrenessansi, baroki ja 19. sajandi akademismi laiutavate töödega.

Teiseks väljendub kunsti invasioon selle ambitsioonides, kunsti sotsiaalsuse rõhutamises, kunsti soovis olla maailmaparandaja ja -reformija, täita teaduse ja ajakirjanduse omadega sarnaseid rolle.

Lõpuks on kunsti invasioon ka aineline, avaldudes kunstile kuluvate materiaalsete vahendite järjekindlas rohkenemises. Need kolm aspekti põimuvad omavahel ja arenenud ühiskonnas näib olevat õilis ja hinnatud kunstile üha rohkem raha kulutada. Kunstnik kulutab raha nagu misjonär maailma muutes ja parandades. Seeläbi õilistub ka rahajagaja roll, olgu selleks siis sponsor või fonditegelane, kes selle tegevuse kaudu vahendab maailma täiustumist.

Siiski tundub, et kunsti invasioon on süütu ja süüdimatu võrreldes keelelise invasiooniga, mis on oma vallutamisviisilt kirjeldamatum, pöördumatum ja mõjusam.

Keeleinvasiooni kõnekaks näiteks on erinevad märk-tüvelised sõnad: märgistama, märkima, märki tabama, ära märkima, üles märkima, märgatavalt, märkimisväärne, märkamatu, märgendama. Samasuguse iseloomuga on ka sõnad jälg, silt, tähistama, nimetama, pealkirjastama.

http://haldjas.folklore.eeltagused/nr24/sarapik.pdf 


\section{Virve Sarapik}

Kategoriseerimine ja nimetamine ongi keeleinvasiooni peamised vormid. Ka kunstiteos peab sobima mingisse kindlasse kategooriasse, olema kas foto, graafika, maal, assamblaaž, tarbekunst. Linnaobjektid jagunevad tänavateks, väljakuteks, elamuteks, büroohooneteks. Eesti kunstnikud jagunevad graafikuteks, maalijateks, skulptoriteks, klaasikunstnikeks jne. Lugedes entsüklopeediatest kunstniku elulugu, saame teada, et meil on tegemist eesti maalija, vene arhitekti, saksa skulptoriga. Samas ei leia me artiklit, kus Vassili Kandinskyt või Mark Rothkot oleks nimetatud juudi kunstnikuks.

Kui kategoriseerimine ja liigitamine on leidnud kunstnike hulgas pidevat vastuseisu, siis teine - nimetamine - on muutunud kunsti enda olemuslikuks osaks. Küllalt huvipakkuv on jälgida, kellel erinevatel aegadel on olnud õigus nime panna. Vanatestamentlik loomine on seotud loodu nimetamisega (Ja Jumal nimetas valguse päevaks ja pimeduse nimetas ta ööks - 1Mo 1: 5), kuid elavatele olenditele nime andmise delegeeris jumal esimesele inimesele: ning tõi nad inimese juurde, et näha, kuidas tema neid nimetab (1Mo 2: 18). Eeva sai nime Aadamalt pärast pattulangemist. Aadama nime saamisest inimese loomise juures otse ei räägita, seda mainitakse alles 1 . Moosese raamatu 5. peatükis: ning andis neile loomispäeval nime: inimene! (1Mo 5: 2).

\section{Nimetamine}

Kui üldiselt saavad lapsed nime vanematelt, siis mõned nimed kirjutatakse jumala poolt ette koos sünni kuulutusega (Ismael 1Mo 16: 11; Iisak - 1Mo 17: 5; Jeesus - Mt 1: 21, Lk 1: 31; Johannes - Lk 1: 13). Enamik Vana Testamendi nimesid on tähenduslikud, nad on pandud lapsele millegi märgiks. Seega tähistab nimi inimest ja veel midagi, mis ei pruugi olla selle inimesega seotud (meenutagem näiteks Jaakobi poegade nimesid).

Eesnimi on alati kellegi poolt pandud nimi ja selle vahetamine on üsna haruldane. Muutmisel peab olema sügav tagamaa või põhjus. Vanas Testamendis oli nimemuutus mingi jumaliku plaani märgiks (Aabrami, Saarai ja Jaakobi nimevahetus). Mõningates kultuurides võib see toimuda kindlatel eluetappidel (initsiatsioon). Seega on õigus oma nime vahetada üks olulisi isikuvabadusi ja nimepanekust ilmselt veelgi suuremat võimu näitab voli kellegi teise nime muuta. 
Nimepanek väljendab igal juhul võimu- ja omandisuhteid. Kui pärisnime panek on isandliku võimu akt - nime paneb tugevam, targem, võimsam - , siis hüüdnimi väljendab narri võimu. Ka see on väline võim, aga pigem anonüümne ja rahvalik. Hellitusnimi, hüüdnime üks vorme, on aga kokkulepe ja vabatahtlik võimu loovutamine teisele. Vanemad kasutavad oma vanemlikku võimu kutsuda last hellitusnimega, kuid sageli paneb laps mingis eas maksma õiguse tegelikule nimele.

Vanatestamentlik loodu nimetamine on tõepoolest üsna tavaline kunstiteosele nimepaneku mudel. Kui kunstnik on teose lõpetanud, signeerib ta selle ja annab tööle nime. On mitmeid kunstnikke, kes delegeerivad nimepaneku kellelegi teisele, muidugi tulemust kontrolli all hoides, nii nagu jumal delegeeris oma loodud elusolendite nimetamise Aadamale, kah enda loodule.

Üsna loomulik on nime maagiline taust ja lai spekter sellega seotud uskumusi. Läheks pikale neid siinkohal täpsemalt kirjeldada, eesti rahvausundi nimeuskumusi on põhjalikult käsitlenud Oskar Loorits ja Ülo Valk (Loorits 1949: 198-250, 1990: 29-33; Valk 1988).

Kokkuvõetuna võib sõnastada mõned printsiibid:

- igal asjal ja olendil saab olla vaid üks ja õige nimi (usk eufemismi kahjutusse ja nt Adam Oleariuse 1647. aastal kirjeldatud komme rahutuid lapsi salaja ümber ristida, arvates, et lapsele on kogemata vale nimi sattunud);

- haiguse ja elusolendi üldnimi samastus sageli pärisnimega, samas kui näiteks kahjutute või huvivabade objektide nimetused ei ole nimed (oluline on ehk ka see, et üldnimi oli vaid võõra olendi jahisaagi ja kiskja - nimeks, koduloomale anti aga pärisnimi);

- nimi on otseses seoses nimekandja reaalse eksistentsiga või on koguni selle osa (kuradi või haiguse nime mainimine põhjustab nende tuleku);

- nime teadmine ja mainimine on tegelikult suhtlemine nimekandjaga, kusjuures on tegemist kahe erineva võimu või mõjutamisviisiga: nime teadmine andis võimu teadjale (nt Ruubentiltsi muinasjutt (AaTh 500 Abistaja nimi) või katkuolendi tundmine (Loorits 1990: 65)), mainimine aga nime kandjale.

Nimes kätkev jõud ning side hinge ja isikuga kandus edasi nimekirjale ning andis sellele maagilise võimu. Huvipakkuv on sellega seoses sõna hingekiri. Kui nimi oli hingekirjas, siis oli kellelgi võim vastava hinge üle. Hingekiri võis olla nii taevase, maise kui allilm- 


\section{Virve Sarapik}

se päritoluga ning viimasest kustutamine aitas hinge oma saatusest pääseda. Kaude on sellega seotud ka väljendid kirja panema ja kirjas olema (elavate kirjas olema, heas kirjas olema).

Nimega seotud vanasõnad väljendavad teist laadi uskumusi ja sisaldavad vähem märke nimetamise ettemääravast võimust:

Ega nimi meest ei riku (EV 7435/125);*

Kuida mies, ninda nimi (EV 6521/3);

Rublane nimi, kopikane amet (EV 9814/17);

Heal lapsel mitu nime (EV 942/60);

Aus nimi on kallim kui kuld (EV 481/15);

Kes teisel nime annab, see seda isi kannab (EV 11838/6);

Hunt jääb hundiks, kui sa teda ka vagaks lambaks nimetad (EV 1623/1);

Kuda au, nõnda nime (EV 458/1);

Nimi ei purõ', ei poksi', ei lü̈̈', ei lömmitä', ei aja' aida ka maha (EV 7439/1).

Siin avaldub pigem vastupidine - nime sõltuvus inimese tegudest. Kuid ka negatiivne märk on märk ja seetõttu võib seda tõlgendada lohutusena nime oletatava väe vastu.

On ka nime võimule ja püsivusele viitavaid vanasõnu:

Kelle laps, selle nimi (EV 5454/60);

Kuidas nimi, nõnda vili (EV 7436/4);

Nime ei mädane hauapõhja ka (EV 7438/2);

Räägi meest, aga ära nimeta meest (EV 9942/65);

Kuidas mehe nimi, nõnda mehe au (EV 6529/1).

Kui nime teadmine on võim ja võib muuta nime kandja reaalseks (kuri, vanatühi, haigused), siis on võimalik ka vastupidine. George Orwell kirjutab oma raamatus 1984:

Su nimi kustutati nimekirjast, kõik jäljed sellest, mis sa olid iial teinud, pühiti minema, su kunagine olemasolu salati maha ja seejärel unustati (Orwell 1990: 17).

Kas sama toimub ka kunstiteosega? Kas pilt hakkab eksisteerima siis, kui sellele pannakse nimi? Kui pole nime, pole ka teost? See on teine relativistlik äärmus esimese - pealkirja määrav roll teose tõlgendamisel - kõrval. Kuid samas on pealkirja vältimatuse kaudu kunstis alati olemas verbaalne invasioon. 
Võimule viitavaid muutumisi näeme ka kohanimede puhul. Kui ühest küljest on kohanimedel omadus elada üle keelemuutusi ja olla seetõttu iidse keelematerjali monumentideks, siis teisalt on oluliste paikade, linnade, riikide, tänavate ümbernimetamine üsna sage võõrvallutustega kaasnev nähtus.

Veel enam väljendab kohanimede muutmine ideoloogilist vallutust. Eesti ajalugu pakub selleks külluslikult näiteid. Võtkem kas või praeguse Eesti Kunstiakadeemia, ilmselt Eesti ühe nimederohkema õppeasutuse nimede rodu: Eesti Kunstiseltsi Tallinna Kunsttööstuskool (1914), Imperaator Aleksander I nimeline Tallinna Linna Kunsttööstuskool (1916), Eesti Vabariigi Tallinna Kunsttööstuskool (1920), Riigi Kunsttööstuskool (1924), Riigi Kõrgem Kunstikool (1938), Jaan Koorti nimeline Riigi Rakenduskunsti Kool (1940), Tallinna Kujutava- ja Rakenduskunstikool (1942), Tallinna Rakenduskunstikool (1943), Tallinna Riiklik Tarbekunsti Instituut (1944), Eesti NSV Riiklik Kunstiinstituut (1951), Tallinna Kunstiülikool (1989), Eesti Kunstiakadeemia (1996). Seetõttu ei tea õieti keegi, mis kooli ta lõpetanud on.

Sellised muutumised on reaalse invasiooni tulemus. Kuid kas on võimalik ka alateadlik, salajane invasioon, mis peegelduks koha või rahvaste nimemuutustes? Kas võib olla ümbernimetamist reaalse allaandmiseta? Miks osa rahvaste nimed on püsivad ja teiste omad mitte?

\section{Märgistamine}

Kui kunstiteosele pealkirja andmine on kõrvutatav sellele nime andmisega, siis tavaliselt toimub teose valmimise järel veel teinegi rituaalne akt - teose signeerimine ehk märgistamine ( $<$ ladina $\mathrm{k}$ signare - märkima, tähistama). Nimepanek eeldab võimu nimetatava üle, kuid samas ka objekti tunnustamist partnerina (nimi pannakse lapsele, koduloomale; nimi on võõral ning vaenulikul jõul). Märgistamine on aga absoluutse võimu ja omandi märk, sellega tunnustust ei kaasne - märgistatakse esemeid, maid, piire, orje, karja.

Signeerimisega asub teost saatma autori nimi - teine vältimatu keele kohalolek. Signeerimise ajalugu võib tagasi viia märksa kaugemale kui teose nimetamise oma. Raamatutele ilmus autori nimi alles mõnda aega pärast trükikunsti leiutamist (varem võis see esineda teksti peidetuna - Genette 1997: 37-39) ning ühe määrava tegurina võib siin mainida ka autori vastutust. Sellele põhjusele on 


\section{Virve Sarapik}

viidanud ka Michel Foucault (Foucault 2000), kuid üheks otseseks ajendiks autori nime ilmumisele oli Trento kirikukogu 4. istungi dekreet 8. aprillist $1546,{ }^{1}$ millele vastavalt ei tohtinud keegi trükkida ega levitada ühtegi autori nimeta usuteemalist raamatut.

Kunstiteoste signeerimine seevastu ulatub antiikaega. Vanimad teadaolevad signatuurid on Kreeka vaasidel 7. sajandist eKr. Signatuuride kaudu on teada ka vanimad kunstnike nimed (Aristonithos, Pyrrhos, Atika maalija Sophilos). Skulptori signatuur ilmus kuju alusele hiljem, 6. sajandi alguses eKr (vanimaks säilinud signatuuriks on [Poly]medes Cleobise ja Bitoni kuju alusel Delfis). Muude tööde signeerimine oli juhuslikum (nt mosaiikidel, Pompeji seinamaalidel) ning hellenismi ja rooma perioodil tähistasid signatuurid skulptuuri alusel koopiategija nime.

Signeerimine tõusis taas esile hiliskeskajal ja vararenessansis, 13. sajandi Itaalias, kuid järjekindlaks traditsiooniks muutus see siiski hiljem. Kindlaid kaanoneid polnud, autori nimi võis olla nii raamil kui ka teose pinnal, võis olla seotud ka pealkirjaga ehk teosel kujutatuga. Enamasti oli signatuur ladinakeelne, kuid mitte alati ja igal pool. ${ }^{2}$ Renessansi signatuurid on tõeline vaatemäng oma üksteist trumpavas fantaasiarikkuses. ${ }^{3}$ Sama liin jätkus klassitsismis ning hooti ka hiljem. ${ }^{4}$ Sellisel kujul nimeesitusele pole 20. sajandi eripalgelisel kunstil midagi juurde lisada, üksikud katsed (eesti kunstis nt paljudel Eduard Viiralti töödel) on vaid mineviku kauge kaja.

Kui nimetamise traditsioon on pigem suuline - pealkiri elas kõnes - , siis autori nimega tungib teosevälja kiri. Selle kirja mõistmiseks peab aga esmalt vaatlema kirja sisu - autori nime tähendust.

\section{Autori nimi}

Iga teos on vältimatult seotud kahe nimega - need on autori nimi ja pealkiri. Ükski kunstiteos pole lihtsalt teos, vaid k e $1 \mathrm{l}$ e g i teos. Kui meil ei onnnestu selgitada selle kuuluvust, on tegemist anonüümse autori teosega, millesse suhtutakse alati teatava ettevaatusega. Kunstilugude illustratsioonideks valitakse meelsamini neid töid, millel on autor. Kindla autorsuse ja anonüümsuse vahele jääb mitmeid poolvariante: Rubensi töökoda, Rembrandti kool, omistatud Brueghelile, Püha Ursula legendi meister jne.

Autorsuse tuvastamine on olnud kunstiajaloo oluline ja teatud pühaduse oreooliga ümbritsetud osa, mille õnnestumistest räägi- 
takse uhkusega kui avastusest. See oleks mõttetu, kui teosel oleks iseseisev, autori nimest täiesti sõltumatu väärtus.

20. sajandil kirjandusteaduse korduvad katsed loobuda autorist ja tema eluloo painest on nagu viktoriaanliku moraali enesepettus. Autori eluloost rääkida pole hea toon, kuid ometi teavad seda kõik. Suhtumine autorisse on kahepalgeline - vältiv ja samas vältimatust tunnistav. Just selle leiduseni viis autori surma järgne Michel Foucault' essee Mis on autor? (Foucault 2000).

M. Foucault päästis autori autorifunktsiooni sõnastamisega. Autorifunktsioon kehastub autori nimes, ta ei määra mitte teose interpreteerimise viisi, vaid selle staatuse ühiskonnas ja kultuuris.

M. Foucault' käsitusest võib jääda kõlama kahe iseseisva märgi võimalus: need on autori nimi ja teose kirjutaja pärisnimi. Mõlema tähistajaks on üks ja sama nimi, mida üks märk seob isikuga, teine teosega. Autori nimi pole pärisnimi, sest kui selgub näiteks, et Shakespeare ei kirjutanud talle omistatud sonette, muutub küll autori nime tähendus, kuid Shakespeare’i kui pärisnime tähendus jääb samaks - ta tähistab ikka sama isikut. Seega autori nimi võib muutuda, pärisnimi mitte. Erinevalt pärisnimest ei välju autori nimi diskursuse sisemusest reaalse indiviidi juurde. Samas näib autori nimi olevat alati kohal, märkides ära teksti piirid, iseloomustades selle olemise viisi.

\section{Pärisnimi}

Pärisnime puhul peab ilmselt vahet tegema selle filosoofilisel ja lingvistilisel kasutusel.

Keelefilosoofilises traditsioonis võib nime käsitlustes eristada kaht suunda. Nimetagem esimest Frege-Russelli-Searle'i nn kirjelduse traditsiooniks (vt nt Frege 1995; Russell 1995a, 1995b; Searle 1958, 1969) - selle järgi on pärisnimel nii osutus kui tähendus (G. Frege Bedeutung ja Sinn). Väljamõeldud objekti nimel (Kalevipoeg, jõuluvana) on küll tähendus, kuid puudub osutus. Ühele osutusele võib vastata ka mitu nime ja vastavalt mitu tähendust (Gottlob Frege liin). Tähenduse moodustab kimp osutuse kohta käivaid määravaid kirjeldusi ning seetõttu pole kirjeldus ja pärisnimi alati rangelt eristatavad (Bertrand Russelli liin). Selle suuna peamiseks probleemiks on üksmeele puudumine tähenduse olemuse osas.

Teist võib nimetada John Stuart Milli ja Saul A. Kripke traditsiooniks, ning selle järgi on nimel vaid osutus, kuna tähendus puudub 


\section{Virve Sarapik}

(vt nt Mill 1872; Kripke 1980). Milli järgi ei ole pärisnime funktsiooniks mitte edasi anda infot, vaid võimaldada üksikobjektil olla diskursi subjektiks; nimed omistatakse objektidele enestele ja nad ei ole sõltuvuses mingitest objekti omadustest (Mill 1872: 20). Üheks põhiküsimuseks selle suuna puhul on väljamõeldud objektide nimed - et neil puudub osutus, siis ei saa neil olla ka tähendust (nt Katz 1998). Siinpakutud skeem on muidugi ülim lihtsustus, kuid just osutuse ja tähenduse küsimus on pärisnime ja autorinime suhtes olulised.

Ideaalne pärisnimi pole otseselt tuletatav objekti omadustest, pole tõlgitav ja on seega mõneti keeleülene, talle vastab kas näiliselt (fiktiivselt) või tegelikult üks objekt, ja ka vastupidi - objektile on pandud just see nimi ning muud kirjeldused on vaid asesõnad. Tegemist on pärisnime abstraktsiooniga, millest kõik tegelikud pärisnimed mingil määral hälbivad, ning seega saab tegelikus keelekasutuses rääkida vaid pärisnime-aspektist. Eesnimi viitab tavaliselt rahvusele, soole, ajastule (kuid ei pruugi seda teha välistavalt); perekonnanimi pole ainuselt osutav; kohanimi viitab oma keelelisele kujunemisele ja kaude ka koha liigile (kuid ei pea seda tegema).

Nimesid ja sõnade nimetavat funktsiooni on sageli seostatud lastekeele teatud arenguetapiga (nt Augustinuse Pihtimused I.VIII; Jakobson 1968; Lyons 1977: 216, 224 jj; Lotman \& Uspenski 1992; Russell 1995a: 79-99). Sellises keeles on sõnade ja objektide suhe otsene ja ühene ning sõnad käituvad nii nagu nimed.

Lastekeele analoogile tugineb paljus ka Bertrand Russelli objektkeel (Russell 1995a: 79-99). Objektsõnad (pärisnimed, tuttavate loomaliikide klassinimed, värvuste nimed) sarnanevad nimedega me omandame nende tähenduse kokkupuutes objektidega, nad ei eelda teisi sõnu ning võivad väljendada tervet väidet (Russell 1995a: 22-23). Kõik objektid ja ka omadused (kollane) on ruumis ja ajas ainused ja seega on neid tähistavad sõnad nimed (Russell 1995a: 127145). B. Russell annab niisiis nimele märksa avarama tähenduse, kuid see on pigem epistemoloogiline laiendus. Jääb alles nime ja tähistatava vaheline otsene ja motiveerimata suhe, kuid samas seab B. Russelli seisukoht kahtluse alla üldnime erinevuse pärisnimest.

Võrdluseks võib kirjeldada üht reaalselt eksisteerinud ja toiminud "objektkeelt". Seda keelt kasutas poiss, nimetagem teda Jonnuks, kolme kuu vältel vanuses 18-21 kuud. Seega oli tegemist omamoodi tõhusa ja ammendava suhtlemisvahendiga. Jonnu keel 
koosnes järgmistest sõnadest: aitäh, dada, päh, mämm-mämm, aiai, opaa, kaka, alloo, auto, alo, ämmä, auh-auh, lilla, tita. Sõnade aitäh, dada, päh, mämm-mämm, ai-ai, opaa, kaka ja alloo (telefon) kasutus vastas tavapärasele lastekeelele, huvipakkuvam on aga ülejäänud nimisõnade oma. Alo (tulenes vanema venna nimest) tähistas kõiki poisse ja noori mehi vanuses 8-30 aastat, soovitavalt lühikeste juustega ja ilma habemeta. Lilla, kontaminatsioon lillest, lusikast ja pliiatsist, tähistas lisaks nimetatuile pikergusi, üldjuhul looduslikke objekte (oksad, lehed, heinakõrred, rood); titat kasutati põhiliselt kaksikutest väikeõe ja -venna, kuid ka tüdrukute ja nais-

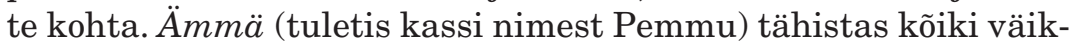
semaid elavaid olendeid ja auh-auh suuremaid. Siin esines küll kõikumisi, näiteks lehmad oli alguses ämmäd ja pärast muutusid auhauhideks, linnud olid üldiselt ämmäd ja esimest korda kaksikuid nähes nimetas Jonnu ka neid nädalapäevad ämmädeks. Üks huvitavama kasutusega sõna oli auto, mis hõlmas lisaks loogilisele seosele - ratastega esemed - kõiki tehislikke ja soovitavalt ka häält tegevaid objekte (nt tolmuimeja, printer ja vaikselt undav elektripost). Vähemalt kolme kuu jooksul, aga paljude sõnade puhul ka kauem oli Jonnu oma kategoriseerimises vääramatu ja valmis igati oma keeletõde kaitsma.

Mõnekuune seisak esimeste sõnade järel iseloomustab laste keele arengut laiemalt. Nimedest koosneva keele puhul oleks aga loomulik oletada sõnade algtähendusele enam-vähem lähedast kasutust. Kirjeldatud Jonnu keel osutab muule - lisaks nimede omandamisele toimub iseseisev üldistus ja selle alusel kategoriseerimine. See toimib mõneti ammendava maailmakirjeldusena - puuduks nagu huvi ja tegelikult ka vajadus uute sõnade järele. Jonnu keele puhul ei saa siiski väita, et see koosneks nimedest, pigem on siin tegemist üld- ja pärisnime kokkusulamisega või keele üheplaanilisusega. Ükski neist sõnadest ei käitunud niivõrd nimena, kuivõrd üldnimena (ka päritolult oli hulgas mõlemaid). Neile vastas kindel üldistus, mõistetasand, mille abil Jonnu ise kategoriseeris tema meelest sobivaid objekte nende nimetuste alla.

Erinevalt Jonnu keelest on B. Russelli objektsõnade tähendus enne nende omandamist olemas, õppimisel ja kasutamisel see ei muutu. Jonnu keel hakkas aga arenema oma loogika järgi ja seal moodustusid omad keelesisesed seosed. Tähenduste teke vastas kõige paremini semantiliste väljade teooriale, mingi teistsuguse sõnade valiku puhul oleksid need ehk olnud ka teistsugused. 


\section{Virve Sarapik}

\section{Tähistamine ja osutus}

Umberto Eco on semantikast tõusnud pärisnime küsimust üritanud taandada, väites, et nii üld- kui pärisnime ja lõpuks igasuguse märgi tähenduseks saab olla vaid kultuuriühik - tunnustekimp, mis ühendab nii selle märgi denotaati kui ka konnotaate ja võimalikke interpreteeringuid (Eco 1976: 66-68). Niisiis on pärisnimi märk nagu iga teinegi. Siiski on U. Eco nõus tegema möönduse tundmatute isikute nimedele, väites, et neile vastab pigem konnotaat kui denotaat, või täpsemalt - nende denotaat on avatud nagu ka meile tundmatu teadusliku mõiste oma (Eco 1976: 88). ${ }^{5}$ Selline lahendus muudaks nime probleemi näiliselt tõesti olematuks. Tuntud isikule vastav kultuuriühik on üldteada, tavainimese oma mitte (aga on ju ka dialekte, mille kõnelejaid on vaid kümmekond) ja see on kogu erinevus. Kui me saame autori kohta teada midagi uut, muutub mõistagi ka kultuuriühik.

Seega märki kasutades - sõna öeldes, mõistele mõeldes - viitame tegelikult oma ettekujutusele, mis sellele märgile vastab. See ettekujutus võib hõlmata nii reaalseid kogemusi, mälestusi kui ka kuuldusi. Lõpuks on reaalse eksistentsi kriteeriumid alati küllalt küsitavad. Selline subjektiivne ja mõõdukas kontseptualism on semiootika kui tähistuspraktika uurimise vaatenurgast põhjendatud. Siiski on kultuuriühik lahendus, mis ei lahenda lõpuks midagi. Pärisnime puhul pole ju probleemiks see, et ta poleks märk, vaid see, et märgina käitub ta üldnimedest erinevalt. U. Eco pakutud lahendus välistab üldnime ja pärisnime erinevuse nagu B. Russelli objektkeelgi, kuid teises suunas - üldmõiste kasuks. Selgineb väljamõeldud olendite nimede küsimus, kuid nime arvel, ehk teisisõnu - jääb vaid tähendus ja kaob osutus.

Reaalne eksistents on kas kogemuslik või tugineb usule - ka usule eksistentsi tõestuse tõesusse (ajalooline isik). Siiski on eksistents oma olemuselt ühtsem kui nime kandev mitteeksistents, fiktsioon. Too võib olla teadlik või ka ebateadlik, põhinedes võltsingul või usul (kurat, tont, tulnukas). Toetumine usule on reaalse ja ebareaalse ühisala.

Kui jätta kõrvale osutus, siis tähistamise akt iseenesest tõepoolest reaalset olemasolu ei nõua. Kui luksuslik auto tähistab meile kellegi rikkust, siis toetub see meie kogemusele ja mitte täpsele teadmisele selle isiku sissetulekust. Kui portree kujutab ja seeläbi tähistab ajaloolist isikut, on kõik seda kinnitavad faktid kaudsed. Kui kujutatud isikut ei teata, toimub ju ikkagi tähistamine, mis 
võimaldab meil seda maali nimetada Tundmatu mehe portreeks. Tähistamise subjektiivsuse esmaseks seadmisest tuleneb aga veel üks tõdemus - otsene ja kaastähendus pole tähistamise seisukohast eristatavad.

Muidugi tekib vaid saussure'iliku tähistamisega tegeldes kiusatus jätta kõrvale segadusi loov väline osutus. Tõesus on ebamugav kategooria ja hetkel, kui kuulutame osutuse tõeväärtuse suhteliseks, asetame ta võimalike maailmade valdusse, asume me tegelema vaid tähistava aktiga.

Välised objektid ning otsese ja kaastähenduse suhe muutuvad oluliseks niipea, kui tähistamise juurest asuda suhtlemise juurde. Peab olema miski, mis võimaldab erinevatel inimestel kasutada ühe ja sama objekti tähistamiseks samu märke, vahetada mõtteid, anda edasi sõnumeid. Umberto Eco kultuuriühik seda küsimust päriselt ei lahenda. Märk ei saa eksisteerida lahus tõlgendamisest ning tulemuseks on peirce'lik piiritu semioos, kus märgi tähendus selgub vaid uue märgi kaudu, mis on eelmise märgi interpretandiks. Märk on märk vaid interpretandi kaudu, mis U. Eco järgi ei pruugi küll kattuda interpreteeriva subjektiga, kuid paratamatult seda siiski teeb. Seega on iga märk kellegi märk, mis piiritu semioosi idee läbi muutub derridalikult hõlmamatuks.

Sellest pääsemiseks (sest suhtluse võimalikkus eeldab märgi mingitki püsivust ja mõistetavust) näib olevat ainus võimalus märki fenomenoloogiliselt selgitada, mis viib aga paratamatult tautoloogiani. Märk on see, mida saame käsitada märgina; keel on see, mida saame käsitada keelena; nimi on see, mida saame käsitada nimena. ${ }^{6}$ Kindlalt määratleda saab neid nähtusi kas aprioorsetena või eituse kaudu, leides selle, mis ei saa olla see märk, see keel, see nimi.

\section{Nimi ja elulugu}

Naaskem nüüd M. Foucault' autori nime ja pärisnime kahestumise juurde. Autori nime lahutamine pärisnimest on tegelikult isiku ja tema tegude lahutamine. Kui eraldamine oleks võimalik, peaks see realiseeruma kõikide inimeste puhul - isiku nimi lahus kõikide tema tehtud tegude tegija nimest. Teodki võivad uute faktide selgumisel, uues kontekstis ajas muutuda. Selline eraldamine viib muidugi paratamatu absurdini ja seega peab nimede lahususe võimalikkuse korral olema piir, mis eristab autorit lihtsalt teo tegijast. Teisalt viitasid nime ja tegude seotusele mitmed eespool too- 


\section{Virve Sarapik}

dud väljendid ja vanasõnad (endale nime tegema; nimi ei riku meest). Kui lähtume teost - teosest ja selle suhtest autori nimega - , taandub pärisnimi autori nime üheks aspektiks. Rääkides Friedebert Tuglasest või Ado Vabbest kui isikust, ei saa me sellest lahutada nende autor-olemist.

Juri Lotman loob siinkohal ühe võimaliku eristuskriteeriumi, rääkides inimestest, kellel on õigus biograafiale, ja teistest, kellel seda õigust pole (näiteks insener ja kunstnik 19. sajandi alguse Venemaal - Lotman 1990: 365 jj). Biograafia kaudu sünnib õigus autori nimele, teo tegija nime eraldamisele pärisnimest. Autori nimi on väärtusi loov siis, kui selle nime taga on biograafia. Biograafia ja autori nime võib tegelikult samastada, nad ongi ühe nähtuse kaks külge.

Kuidas on aga autori nimi seotud pärisnimega - kas on tegemist ühe märgi denotaadi ja konnotaatide reaga (ja kumb on siis kumb) või kahe eraldi märgiga? Biograafia kui autori nime tekkimise kriteerium annab ka siin vastuse. Kui isik omandab autori nime ja saab biograafiaga isikuks, toimub nihe - autori nimi saab esmaseks, pärisnimi selle konnotaadiks (näiteks kohvikuvestlus kuulsustest: ma tunnen isikut, kes peitub autori nime taga, seega autori nime kaastähendust).

Autori nime esmasus kehtib siis, kui lähtume teosest. Igapäevaelus elab autor oma elu oma pärisnimega ja see elu pole biograafia. Igapäevane elu on teosega võrreldes teine semiootiline süsteem ja samal märgil on teises süsteemis teistsugune tähendus. Kahte erinevasse süsteemi kuulus ka pealkiri - üheks oli side teosega ja teiseks pealkiri kui keeleväljend. Ka pealkirja tähendus muutus, kui ta teosest lahus asus oma tegelikku, lingvistilisse ümbrusse - kui sõnad pea või mees piibuga elavad keeles ja tähistavad lihtsalt pead ja meest piibuga. Peamiseks erinevuseks autori nimest on see, et pealkiri kaotab ilma teoseta oma pärisnimelikkuse, autori nimi võidab selle tagasi. Seega liiguvad pealkiri ja autori nimi vastassuunas.

Kui pealkiri on pärisnimi oma nimetava funktsiooni kaudu, siis autori nimi suhtes teosega pärisnimi ei ole. Autori nimi on klassinimi, võrreldav žanri ja tehnikaga, kuid erinevalt neist loob autori nimi väärtusi, on hinnanguline. Ühe autori teosed on hinnatumad kui teise omad, teos võib kuuluda ühe autori tippude või ebaõnnestumiste hulka. Kui pealkiri oli teose interpretatsiooni käivitajaks, siis autori nimi käivitab liikumise hinnangulisel skaalal. Interpretatsioon on muutuv ja lähtub lugejast, hinnang pürib absoluutsusele. 
Autori nimi loob teostest ühtse rühma ja erinevalt muudest kategooriatest on selle piirid jäigad: autori nimi on see, mis on teosele kaasa antud. Samas on autori nime teadmine nagu pealkirja lugemine - pärast seda vaatame me tööd teistmoodi, vaatame seda kui Eduard Viiralti, Johannes Võerahansu, Jaan Toomiku tööd ja mitte lihtsalt pilti.

Muidugi võib siinkohal kuulda vastuväiteid ühest märgisüsteemist teise liikumise kohta. Kas ei oleks näiteks õigem rääkida konteksti vahetusest? Või väita, et autori, ütleme William Shakespeare'i puhul on tegemist klassikalise homonüümia (mis tuleneks Michel Foucault'st) või polüseemia näitega?

Väites, et muutub vaid nime kontekst, et ühes kontekstis on nimi pärisnimi ja teises autori nimi, otsest vastuolu seniöelduga muidugi pole. Kritiseerida saab eeskätt konteksti mõistet - see on nähtus, mis iseenesest ei ütle midagi uut, on võrratult paljulubav ja kõikeneelav nagu soo, keeldudes kiivalt midagi tagasi andmast. Konteksti käsitlusel peab ikkagi tooma sisse arvukalt tugimõisteid ja piiranguid, et ta muutuks osaltki hõlmatavaks. Et kontekstist oleks kasu, saame seda käsitleda vaid teise, kas või tundmatu teksti või taustsüsteemina (vrd nt ka Veidemann 1997).

Teise küsimuse - homonüümia - selgituseks vaadelgem lähemalt ühe märgi käitumist erinevates süsteemides. Erinevalt tavapärasest homonüümia ja polüseemia suhtest peaks eristama nelja olukorda, kus märgi väljendus ehk tähistaja on vormilt identne. Loomuliku keele näitel võib võrrelda järgmisi võimalusi.

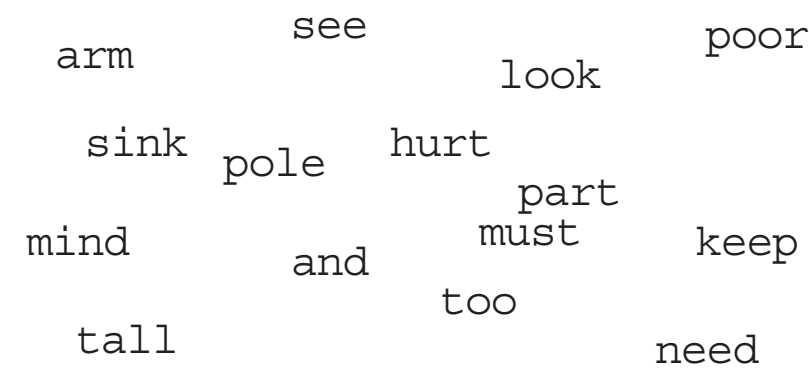

1. Erikeelsed lekseemid, mille semeemidel puudub igasugune seos. Siinjuures võib tekkida illusioon ühest või teisest keelest või ka kahest korraga, mis tekitab värelusi erinevate tähenduste vahel. Tekib pilt, mida võib võrrelda tajupsühholoogias tuntud illust- 


\section{Virve Sarapik}

ratsiooniga, millel me näeme kas vaasi või kahte vestlevat nägu.

2. Samakeelsed lekseemid, mille semeemidel puudub igasugune seos (tavaline homonüümia - lest, tee).

3. Üks lekseem, millel on mitu semeemi (polüseemia - valge).

4. Erikeelsed lekseemid, mille semeemid kattuvad kas täielikult (nt pärisnimi) või osaliselt (nt auto, bass, diskrimineerima eesti ja inglise keeles).

Autori- ja pärisnime tähenduse muutust iseloomustab aga veelgi täpsemalt mitte keele, vaid alamkoodi muutumine. Sobivateks paralleelideks võiksid olla viisakuse alamkood (olge nii kena) ja fraseologismid laiemalt (mustas meeleolus) ja kattuvad mõisted erinevates teooriates (kaos kaoseteoorias ja mütoloogias). Probleem on sarnane: kas tegemist on kahe erineva märgi või ühe märgi liikumisega teise süsteemi, mis elavdab tema kaastähendusi (seega kahe erineva keele osaliselt kattuva märgistikuga)? Nende näidete puhul jääb märgi algne tähendus teises süsteemis alles, just sellele tugineb fraseoloogia võlu ja veetlus.

Juri Lotmanilt pärineb tuntud ja analooge lubav teiseste modelleerivate süsteemide mõiste. Teisene süsteem eeldaks aga, et esmasus on eristatav. Teisene süsteem peaks toetuma mingile algkeelele - üheselt mõistetavale, võiks öelda koguni eelpaabellikule keelele. Samas kumab ka J. Lotmani arutlustest läbi esmase keele tunnetamatus (kunstikeel, müüdikeel). Paljude teisest modelleerivat süsteemi eeldavate nähtuste puhul saamegi enamasti lähtuda olemasolevast ja hoomatavast tähistusest, jõudmata esmasuseni kunagi. Seeläbi muutub aga vähemalt siinse teema puhul kahtlaseks esmasuse printsiip tervikuna.

Autori- ja pärisnimi liiguvad niisiis erinevates süsteemides ning autori ja teose suhte seisukohalt ei saa me öelda, et pärisnime (või autori kui inimese argielu) süsteem oleks esmane. Nimi on märk, mis näiliselt muutumatuna liigub ühest süsteemist teise ning mõistagi kipuvad piirid nende erinevate semiootiliste süsteemide vahel hajuma. Näiteks kui Mees piibuga on tegelikult autoportree kunstnikust, ${ }^{7}$ kes ise piipu tõmmata armastab, ja teose arvustaja just piibutõmbamise aluseks võtab:

Käesolev näitus on huvitav seepoolest, et esineb koos kaks organisatsiooni: Rühm, mille vormiatribuudiks on piip ta täisõiguslikel liikmeil, ja Keskühing, mille liikmed ei ole jõudnud piibuni, tihti mitte paberossinigi. [---] Mind huvitab kôige muu 
mööbli seast ainult piip, sest tal on ülesandeks anda suur nikotiinielamus, kuid ta vorm on kategooriline ja lihtne ning lõpuni otsustatud. Ja sellepärast: piipude kaudu kunsti juurde.

Onnelik juhus on tutvustanud mind Märt La a r mani [---] pika vimmas kogu, A $r n$. A $k$ b e $r g$ g palja peaga varustatud valju näo, H e n rik O lvi tasakaalus heasüdamliku isiku ja lõuahabemes E. O l e'ga. Ja need ongi Rühma tormajad - piibumehed, konstruktivistid, kes tahavad viia kunsti ellu ning on leidnud õige alge piibust. [---]

Raske on eraldada Keskühingu mehi üksteisest. Rühma piibumeestel on igaühel omalaadiline $p$ i i $p$ - mõnel tüse nagu bulldog, mõnel sale nagu suitsetaja ise, ühel tugev teisel nõrk, sellane piibuga nägu jääb paremini meele - selle võib märkida ära kas vôi piibukatalogi (Andresen 1927).

\section{Nime jälg ja varjunimi}

Kuigi M. Foucault leiab, et autori nime on võimalik pärisnimest eraldada, et autorifunktsioon ei pea reaalsele isikule osutama, siis ilmselt see siiski nii ei ole. Pärisnimi küll lahkub süsteemist teosautorinimi, kuid midagi temast jääb alles. Alles jääb vaikiv teadmine isikust. Just see vaikiv teadmine, millest ei sobi rääkida, on üheks autori nime staatust määrava funktsiooni aluseks. Seega pärisnimi (ja ühes sellega osutus) lahkub näiliselt, kuid temast jääb järele jälg - õonesvorm. Ajaloolisel, tundmatu elulooga autori nimel võib see jälg olla nõrgem või kulunum. Elavate autorite jälg on selge ja terav, mõjutades teoste lugemist ja vaatamist. Isiku reaalsed teod elavad paratamatult koos tema autorinime ja teostega elav kunstielu ei lase teost suletud torni.

Üheks toodud väiteid selgitada aitavaks nähtuseks on pseudonüüm. Kõige lihtsam skeem - üks inimene kasutab püsivat ja üldtuntud pseudonüümi - midagi olulist ei muuda, pärisnime sageli isegi ei teata. Sellise pseudonüümi päritolu on ähmane, selleks võib olla ka neiupõlve- või emanimi (Picasso, Villon). Keerukam on lugu teadlikult loodud fiktiivsete autorikujudega, mille taga võib olla rohkem inimesi (Matti Moguči, Albert Trapeež, Ene Hölderlin, Nelli Rohtvee) ja kellele vahel on loodud ka biograafia (Arthur Valdes). Eesti kultuurilugu on pseudonüümirohke ja paljus johtub see ajaloost. 20. sajandi alguse kirjanikud võtsid saksapäraste perekonnanimede asemele eestikeelseid pseudonüüme, ajakirjanduses oli pseu- 


\section{Virve Sarapik}

donüüm pigem reegliks, vahel kaasnes nimevahetusega poliitiline taust, mitmete nõukogudeaegsete varikujude tööd liikusid lubatavuse piirimail jne.

Gérard Genette on pakkunud välja kirjanduslike varjunimede liigituse, veidi mugandatuna oleks see järgmine:

1) anonüümsus, autorinime nulltasand, sealjuures anonüümsus de facto puuduvate andmete tõttu ning peidetud-krüptiline või peidetud anonüümsus;

2) apokrüüf - kas teadlik võltsing või teadmatusest tingitud teose omistamine teisele autorile, harvem juhus - apokrüüf autori loaga (kunstis on võltsingu piirid ajalooliselt veelgi segasemad ja hukkamõistu pälvivaks nähtuseks on see kujunenud alles viimastel sajanditel);

3) plagiaat - võõra teose avaldamine oma nime all, jällegi haruldasema võimalusena plagiaat autori loaga (Alexander Dumas' vanema ja Auguste Maquet' juhtum, kunstianaloogiks võiksid olla autori töökoda ja koolkond);

4) väljamõeldud autor;

5) pseudonüüm selle tuntud tähenduses (lihtsalt teise nime all avaldamine ilma muu kaasneva paratekstuaalse lisandita). Siin võib omakorda eristada püsivat isiku ja autori nime erinevust (nt Mait Metsanurk, Andres Vanapa, sh nimemuutus) ning teadlikku varjunimemängu, mille kaugemaks sihiks ja mõtteks on õige autori väljaandmine (Christian Steen, Emil Tode). Keerukamateks vormideks on ühe autori mitu pseudonüümi (vrd Genette 1997: 46-51). ${ }^{8}$

G. Genette märgib ära ka selle, et pseudonüüm on kirjanduses levinum kui kunstis, muusikas ja arhitektuuris. Kuid - ja see tundub G. Genette'ile enesestmõistetav - pseudonüümide kasutamine on liialt seotud maskide ja peeglite, kaudse ekshibitsionismiga, onomastilise fetišismiga. Pseudonüümi kasutamine on juba iseenesest poeetiline tegevus, pseudonüüm sarnaneb mõneti teosega.

Kui sa oskad oma nime muuta, oskad sa kirjutada (Genette 1997: 53-54).

Kunstis võib selle põhjuseks siiski olla ka muu. Kunstniku nimi kui (kauba)märk peab olema tõepoolest püsiv. Püsiv on ka kunstniku varjunimi - kord juba võetuna see naljalt ei muutu. Ehk teistpidi, 
kuna kunstis on endale nime tegemine oluline ja raske, ei saa keegi endale lubada asjatutjõukulu paljude erinevate nimede tegemise peale. Kirjanduses on pseudonüüm sõna teiste sõnade keskel. Mäng pseudonüümiga tugineb paljus teadasaamise mõnule ja on hästi kõrvutatav omaenese eluloo kirjutamisega.

Pseudonüümiga seguneb lõputu variaablus nimevahetusi ning see võib lõpuks asendada ka isiku nime (Tuglas, Lenin). Endale nime tegemisega (autori nimi) kaasneb siin selgelt ka õ i g u s nime vahetamisele - see õigus on antud kirjanikule või ka kunstnikule kui erilisele olendile. Eesti ajalugu, nagu juba viidatud, pakub sellele teemale rohkesti ainet. Nimevahetus on isikuvabaduse akt ja üheks oluliseks momendiks on nimede eestistamine kui laiendatud kodukaunistamine ja lõplik eneseveenmine 700 -aastase orjaaja painest vabanemises. Muidugi pole selle näite puhul tegemist pseudonüümiga, kuid kunsti- ja kirjanduslooliselt on see ja reaalne nimevahetus paiguti eristamatud.

Teiseks Eesti omapärasuseks on empiiriliselt adutav neiupõlvenime-lembesus. Ehk seostub see kaude ka eesti võimsa naisluule (ja naiskunstiga), kuid vähemalt kunstnike hulgas on neiupõlvenime ja kunstnikunime samastumine pigem reegel kui erand.

Ahvatlevaks võimaluseks on pidada pseudonüümi tüüpolukorraks, mis lahutab autorinime ja pärisnime. Selle kaudu ongi meil kaks nime, kaks märki, kaks tähendust. Paraku jääb pärisnime jälg alles ka siin, lahutamine pole täielik ja selle jälje teravus sõltub lugeja teadmistest või ka laiemalt hetketeadmistest autori kohta (mis ongi selle hetke tõde).

Seega on pseudonüüm autori nimega võrdselt staatust loov vaid siis, kui ta asendab isiku nime täielikult. Ajutised pseudonüümid, need, mille taga peitub algne kava saada avastatud, autori nimega ei samastu. Selle lahingu võidab üks püsiv autori nimi ning jälg minevikust võib ainet pakkuda vahest veel loogikutele (nt Walter Scott ja Waverley autor).

Osaline nimemuutus on kõrvutatav fiktiivse autori loomisega. Mõlemad on kavatsuslikud tõe varjamised, mille eesmärgiks on selle varjamise rõhutamine. Fiktiivse autori teoste staatus on madalam. Sama võib olla ka ajutise varjunime puhul (näiteks peasuunast erinevate tööde avaldamine teise nime all).

G. Genette’i väiteid pseudonüümi sõnakesksuse kohta kinnitavad Albert Trapeeži ja Nelli Rohtvee juhtumid. Mõlemad on seotud kunstiga, kuid peamiselt selle sõnastamisi vajanud küljega - ar- 


\section{Virve Sarapik}

vustused, traktaadid ja muidulood. Seega uus autor loodi peategevusest hälbiva kattevarjuks ning oleks mõttetu hakata nende nimede all avaldatu autentsust taga ajama. Siiski ei saa selliste nimede ülesannet võrrelda päriselt autori nime funktsiooniga - nende eesmärk on olla autori puudumise märgiks. Fiktiivset autorit võib võrrelda hüüdnimega. Kui autori nimi kehastab autorifunktsiooni, siis hüüdnimi kehastab narrifunktsiooni.

Autori nimi loob teose staatuse, tuntud autori marginaalne või ka halb teos on sageli olulisem kui tundmatu autori peateos. Anonüümne tuntus on seega teose ülim tunnustus. Oleks huvitav teada, kui palju maale on hävinud viimasel sajandil autori nime puudumise tõttu. Trükitud raamatud on ehk õnnelikumas seisus - neist säilib mingi koopia raamatukogus, mida küll võib-olla keegi kunagi ei loe. Seega luues teose staatuse, loob autori nimi teose lugemise viisi. Kuulumata küll teose teksti on ta samas ikkagi teose eksistentsi üheks tagatiseks.

\section{Autorimetonüümia}

Teose täpne määratlemine eeldab nii autori kui ka pealkirja mainimist. Kui autori nimi asendab kõnes teost, võime seda nimetada autorimetonüümiaks. Pealkirja käsitluses leidsime, et kunstist rääkimisel on autori nime metonüümiline kasutus levinum kui teistel aladel. Ilmselt võib sama väita ka autori nime olulisuse kohta. Peab siiski märkima, et ka muusikast kõneldes on autorimetonüümia sage (kuulasin Pärti, Mozartit, mängiti Mussorgskit, kontserdi kavas olid... jne) ning siin on sidet teose kaubalisusega (nagu kunsti puhul) raske oletada.

Autorimetonüümia on enamasti kahekordselt metonüümiline eesnimi kaob ning kõigepealt jääb autorit ennast ning selle kaudu ka teost tähistama vaid perekonnanimi või pseudonüüm (Metsanurk, Kivisildnik). Üsna käepärane on lausuda vaatasin muuseumis Viiraltit, Vabbet ja Võerahansut, kuid samas Konrad Mäge ja Karin Lutsu; ${ }^{9}$ lugesin Underit ja Liivi Anna Haavat. Nii tugineb autorimetonüümia kindlasti autori tuntusele, aga ka nime kõlale, ainulaadsusele ja kõnekusele.

Tuntud teostest rääkides autorile sageli ei viidata ( $m a$ loen Tõde ja õigust, teatris mängitakse Hamletit, vaatasin Louvre'is Mona Lisat). ${ }^{10}$ Ka filmide puhul on esmatunnuseks pealkiri, režissööri nimi filmi ei asenda. Selline vorm on - autori ja pealkirja kombinatsioo- 
ni asendab vaid pealkiri - mõneti samuti metonüümiline ja nii võime seda nimetada pealkirjametonüümiaks.

Kirjanduses võib pealkirjametonüümiat kohata laste- ja massikirjandusest rääkides ning vahel võib asendaja kohale asuda ka peakangelane - Sipsik, Tarzan, Fantoom tähistavad kõiki nendega seotud raamatuid. Nii ongi pealkirjametonüümia ehk rohkem massikultuuriga seotud - massikultuur on autori surm enne tema ellu ärkamist. Teisalt eeldab pealkirjametonüümia alati originaalset ja head pealkirja, mis suudaks teost tähistada ka ilma autorita. See on teose ülima tuntuse tunnusmärk, kuid tuntus autori nime arvel.

Argikõnes võivad pealkiri ja autori nimi seega olla teosest rääkimisel võrdses rollis ja teineteist asendada. Narratiivsemad kunstiliigid kalduvad eelistama pealkirja, mittenarratiivsed autorit. Kunstist rääkides on autorimetonüümia kõige sagedasem maastike, abstraktsioonide, natüürmortide puhul. Ehk saab seda kõrvutada ka autorimetonüümiaga muusikas. Muusikapealkirjad on temaatilised, korduvad ja keerukad, teoste meeldejätmine nõuab pühendumust ja kogemust. Nii muutubki autor muusikas ainuvõimalikuks metonüümia lähteks. Arhitekt kui looja pole tavateadvusse jõudnud, arhitektuuris kõneleb hoone funktsioon ja mitte hoone kui teos. Sellest ehk ka autorimetonüümia puudumine. Metonüümia teose tähistajana, nime asendajana on tuttavlikkuse tähis, selle lähem uurimine võiks anda mõndagi teada vaataja ja lugeja suhtumistest.

\section{Kommentaarid}

*Eesti vanasõnanäidetes märgib esimene number tüüpi ja teine variantide arvu.

${ }^{1}$ Waterworth, James (toim \& tõlk) 1848. The Council of Trent $=$ The Canons and Decrees of the Sacred and Ecumenical Council of Trent. London: Dolman (viidatud: Hanover Historical Texts Project: http://history.hanover.edu/ texts/trent/trentall.html - 14. oktoober 2003).

${ }^{2}$ Näiteks Jan van Eycki Arnolfini abielupaar (1434, Londoni National Gallery), kus abielupaari vahelt seinalt paistab uuristatud kiri Johannes de eyck fuit hic. / .1434 (Johannes de Eyck oli siin. / .1434).

3 Toome vaid mõned näited. Üks itaalia renessansis levinud nime kirjutamise mooduseid oli cartellino - illusoorselt maalitud pärgamendi- või paberitükk, millele kirjutati autori või kujutatu nimi. Selle võtte üks in- 


\section{Virve Sarapik}

nukamaid kasutajaid oli Giovanni Bellini. Tema maalil Doodž Leonardo Loredani portree on cartellino kinnitatud rinnatisele (1501-1504, Londoni National Gallery), maalil Püha Peetruse märtrisurm (u 1507, Londoni National Gallery) ripub paberi- või pärgamenditükk kunstniku nimega üle puuoksa. Raffaeli maalil Kristuse ristilöömine Neitsi Maarja, pühakute ja inglitega (u 1503, Londoni National Gallery) on risti allosas nagu uuristatult RAPHAEL / VRBIN / AS / P (Urbino Raffael maalis selle). Väheseid Diego Velásqueze signeeritud töid on Hispaania Felipe IV pruunis ja hõbedas (1631-1632, Londoni National Gallery), millel kuningas hoiab käes kirja kunstniku nimega. Hans Holbein noorema maalil Erasmuse portree (1522, Londoni National Gallery) on taamal seinal oleval raamaturiiulil raamatukaanel rooma numbritega 1522 ja küljel halvasti loetavalt Mina olen Johannes Holbein, keda on kergem mustata kui matkida. Fantaasiarikkamaid signeerimismeistreid kunstiajaloos oli aga ilmselt Albrecht Dürer.

${ }^{4}$ Nt Nicolas Poussini autoportree (1650, Pariisi Louvre) kirjaga Effigies Nicolai Poussini Andelyensis Pictoris. Anno Aetatis 56. Romae Anno jubilei 1650 (Maalija Nicolai Poussin des Andelysi portree 56 aasta vanuses, Roomas aastal 1650); Jacques-Louis David' Marat' surm (1793, Brüsseli Musées Royaux des Beaux-Arts) postamendile uuristatud kirjadega À MARAT/ $D A V I D$ ja hilisemast ajast Van Goghi Päevalilled (1888, Londoni National Gallery), kus nimi VINCENT sulab kokku lillevaasi ornamendiga.

5 Üsna sageli kasutakse denotaati osutuse (kas siis G. Frege Bedeutungi või Charles Kay Ogdeni ja Ivory Armstrong Richardsi referenti tähenduses) sünonüümina (nt Lyons 1977: 213). Teine seisukoht, mida esindab Umberto Eco, loeb denotaadi intensionaalseks (reaalsusest otseselt sõltumatuks) ning seega esindab seda Ferdinand de Saussure'i tähistaja ja tähistatava dihhotoomia või Louis Hjelmslev' väljenduse ja sisu suhe (Eco 1976: 54-66). Sisu hõlmab nii denotaati kui ka konnotaate ning vajadusel ka seoseid võimalike välise maailma seisunditega. Seega võib öelda, et U. Eco denotaat, rääkimata märgi sisust, on märgatavalt laiem mõiste kui G. Frege Sinn. Konnotaati kasutab U. Eco pigem selle tavatähenduses kui kaastähendust, erinevalt J. S. Millist lähtuvast traditsioonist, kellel konnotaat on denotaatide ühine üldomadus (nt koeralikkus või punasus).

${ }^{6}$ Vrd aga ka nt G. Frege: Pärisnime tähenduse haarab igaüks, kes tunneb piisavalt keelt või tähiste kogumit, kuhu see kuulub (Frege 1995: 88), B. Russell: Kui ei ole alust vastupidiseks, võime oma eesmärkide jaoks tunnistada nimeks kõik, mida harilikult selleks peetakse (Russell 1997: 129).

${ }^{7}$ Vrd nt Märt Laarmani arvukad autoportreed piibuga.

${ }^{8}$ Veel võib viidata Doris Kareva sõnastatud Hasso Krulli G. Genette'ist inspiratsiooni saanud pseudonüümide käsitlusele seoses Matti Moguči isikuga (Kareva 1999). 


\section{Virve Sarapik}

${ }^{9}$ Muidugi ei saa metonüümia kasutuse kohta väita midagi absoluutselt, see sõltub kontekstist, ajast ja paljust muust - võrdluseks olgu kas või ning seinal Mägi värvehõiskav maal (Marie Underi "Interjöörid” kogust Sinine puri).

${ }^{10}$ Huvipakkuv on ka Tõnu Õnnepalu raamatute metonüümia - öeldakse lugesin "Piiririiki”, kuid Emil Tode "Printsessi”(Piret Viirese märkus).

\section{Kirjandus}

Andresen, Nigol 1927 = Vagabundus. Piibuga ja piibuta kunstnikud kevadnäitusel. Rahva Sõna, 20. mai.

Augustinus, Aurelius 1993. Pihtimused. (Confessiones.) Tallinn: Logos.

Eco, Umberto 1976. A theory of semiotics. Bloomington: Indiana University Press.

EV = Krikmann, Arvo \& Sarv, Ingrid (toim) 1980-1988. Eesti vanasõnad IIV. Tallinn: Eesti Raamat.

Foucault, Michel 2000. Mis on autor? Vikerkaar 11-12, lk 156-172.

Frege, Gottlob 1995. Tähendusest ja osutusest. Akadeemia 1, lk 87-108.

Genette, Gérard 1997 Paratexts: Thresholds of Interpretation. Cambridge: Cambridge University Press.

Jakobson, Roman 1968. Child Language, Aphasia and Phonological Universals. Hague: Mouton de Gruyter.

Kareva, Doris 1999. Autor välja! Sõnumik. Sirp 8, 26. veebruar.

Katz, Jerrold J. 1998. Names Without Bearers (http://www.nyu.edu/gsas/ $\mathrm{dept} /$ philo/courses/concepts/katznames.html - 2. veebruar 1999).

Kripke, Saul A. 1980. Naming and Necessity. Cambridge: Harvard University Press.

Loorits, Oskar 1949. Grundzüge des estnischen Volksglaubens 1. Skrifter utgivna av Kungl. Gustav Adolfs akademien för folklivsforskning 18:1. Uppsala \& Köpenhamn: Lundequistska Bokhandeln \& Munksgaard.

Loorits, Oskar 1990. Eesti rahvausundi maailmavaade. Tallinn: Perioodika.

Lotman, Juri 1990. Kultuurisemiootika. Tallinn: Olion.

Lotman \& Uspenski 1992 = Лотман, Юрий \& Успенский, Борис. Миф имя - култура. Лотман, Юрий. Избранные статьи І. Таллинн: Александра, lk 58-75.

Lyons, John 1977. Semantics I. Cambridge: Cambridge University Press. 


\section{Virve Sarapik}

Mill, John Stuart 1949. A System of Logic. London: Longmans, Green and Company.

Orwell, George 1990. 1984. Loomingu Raamatukogu 48-51. Tallinn: Perioodika.

Russell, Bertrand 1995a. Uurimus tähendusest ja tõest. Tallinn: Hortus Litterarum.

Russell, Bertrand 1995b. Osutamisest. Akadeemia 3, lk 526-542.

Searle, John R. 1958. Proper Names. Mind 67, lk 166-171.

Searle, John R. 1969. Speech Acts. London \& New York: Cambridge University Press.

Valk, Ülo 1988. Eesti nimeuskumusi. Vikerkaar 9, lk 39-42.

Veidemann, Rein 1997. Kriitika kui kontekst. Keel ja Kirjandus 9, lk $585-591$. 